\title{
Listy emigrantów
}

\section{Marcin Lutomierski}

(Uniwersytet Mikołaja Kopernika, Toruń)

Jan Lechoń, Kazimierz Wierzyński, Listy 1941-1956, oprac. Beata Dorosz przy współpracy Pawea Kądzieli, Wydawnictwo Instytutu Badań LiTERACKICH, WarsZaWA 2OI6, ss. 643

Recenzowany tom jest zbiorem listów pisarzy (oraz żony jednego z nich), którzy od I939 roku przebywali na uchodźstwie, a po zakończeniu wojny wybrali emigrację. Autorami korespondencji są dwaj słynni już przed wojną poeci - Jan Lechoń i Kazimierz Wierzyński (z żoną Haliną), choć ich list pochodzą z lat I94I-I956. Ponieważ był to czas, kiedy obaj pisarze przebywali na obczyźnie, warto chociaż zasygnalizować szczególną rolę listu na uchodźstwie i emigracji.

W swojej książce o tzw. polskim Londynie Rafał Habielski przypomina, że po wojnie listy, a nie telefony - wówczas niezbyt dostępne - były sposobem na kontaktowanie się Polaków ${ }^{\top}$. Należy również wziąć pod uwagę fakt niezwykle dużego rozproszenia ówczesnej polskiej diaspory, zamieszkującej niemal wszystkie kontynenty. Takie warunki praktycznie uniemożliwiały normalne istnienie życia literackiego, dlatego list oprócz oczywistych funkcji integracyjnych zastępował np. instytucje kultury i organizowane przez nich wydarzenia, był formą odzewu czytelniczego czy nawet krytyki literackiej.

Na potrzebę badań korespondencji pisarzy, redakcji i oficyn wydawniczych zwracali już uwagę m.in. Anna i Mirosław Supruniukowie². Podkreślali oni nieprzemijającą wartość publikowanych na podstawie rękopisów materiałów źródłowych, przytaczając bardzo ważne zdanie Pawła Kądzieli, współedytora recenzowanego wydania:

\section{\ Kto wie, czy w miarę ujawniania prywatnych archiwów i udostępniania zbiorów epistolarnych zasłużonych ośrodków wydawniczych emi-}

1 Zob. R. Habielski, Polski Londyn, Wrocław 2000, s. 43.

2 A. i M.A. Supruniukowie, Archiwum "Wiadomości”, w: „Wiadomości” i okolice. Szkice i wspomnienia, red. i oprac. M.A. Supruniuk, t. 1, Toruń 1995, s. 122-123. 
gracji politycznej po i939 r. [...] nie okaże się, iż to, co na obczyźnie powstało najciekawszego, co pozostanie jako wspaniały, najciekawszy dokument historyczny ostatniego półwiecza, to nie spisane pod koniec życia, retrospektywne i często wymagające wielu uściśleń i weryfikacji pamiętniki oraz wspomnienia, lecz listy, których nadawcy reagowali natychmiast na wydarzenia, listy, w których przechowany został klimat epoki³.

Na wielowymiarowość źródła, jakim jest korespondencja emigrantów, wskazywał również Maciej Wróblewski, który konstatował: „tajemnica zawarta w liście emigracyjnym jest czymś więcej aniżeli zapisem wyłącznie osobistych zdarzeń; wykracza poza obszar dokumentu osobistego, przybierając często formę zbliżoną do utworów literackich lub paraliterackich"”.

Przyjrzyjmy się teraz listom przygotowanym do druku przez Beatę Dorosz we współpracy z Pawłem Kądzielą. Zebrana w obszernym tomie edycja korespondencji pochodzi z dwóch źródeł - Biblioteki Polskiej Polskiego Ośrodka Społeczno-Kulturalnego w Londynie (Wierzyński) oraz Polskiego Instytutu Naukowego w Ameryce (Lechoń). Oprócz prawie 230 wcześniej niedrukowanych listów wydanie zawiera aneks w postaci okolicznościowych kartek z życzeniami, niewysłanego listu Lechonia do Wierzyńskiego, korespondencji Haliny Wierzyńskiej i Jana Libracha (na temat listów obu poetów), wypowiedzi autorów o sobie, a także 38 mało lub w ogóle nieznanych fotografii oraz indeksu osób (opracowanego przez Andrzeja P. Lesiakowskiego).

W głównej części tomu autorami większości listów (ok. 70\%) są Kazimierz i Halina Wierzyńscy, a pozostałych - Jan Lechoń, choć jego wypowiedzi mają znacznie większą objętość. Tematyka listów jest zróżnicowana - od bieżących informacji o samopoczuciu, procesie twórczym i wykonywanych zajęciach, przez uwagi czytelnicze i recenzyjne czy reakcje na wydarzenia, aż do rozmaitych spraw emigracyjnych i krajowych. Jak mówią edytorzy, listy pokazują „sylwetki obu bohaterów na tle literatury, kultury, historii i polityki owego czasu, a nade wszystko rysując ich portrety osobiste” (s. 23). Listy poetów-erudytów stanowią kulturowy „las rzeczy" z całą plejadą znanych i nieznanych dziś postaci w tle. Wszystko to sprawia, że udostępniona korespondencja jest niezwykle cennym - bo wielowątkowym i wielowymiarowym - źródłem wiedzy o kulturze polskiej na obczyźnie. Pomimo

3 P. Kądziela, Listy Kazimierza Wierzyńskiego do Jana Parandowskiego, „Roczniki Humanistyczne” 1991-1992, t. 39-40, z. 1, s. 127.

4 M. Wróblewski, Między dokumentem a literatura - o różych funkcjach listu emigracyjnego, w: Powroty w zapomnienie. Dekada literatury emigracyjnej 1989-1999, red. B. Klimaszewski, W. Ligęza, Kraków 2001, s. 283. 
fizycznego oddalenia od „polskiego Londynu” autorzy wciąż pozostają w centrum spraw emigracyjnych, reprezentują bowiem uchodźstwo i emigrację o rodowodzie wojennym i bliska jest im postawa „niezłomnych, nieprzejednanych”. Współpracują z „Wiadomościami Polskimi, Politycznymi i Literackimi” oraz ich kontynuacją jako „Wiadomości”. Nie tylko publikują tu swoje utwory lub ich fragmenty, lecz także są uważnymi czytelnikami i komentatorami czasopisma, którego twórcą i wieloletnim redaktorem był Mieczysław Grydzewski. Ukazujący się w Londynie tygodnik miał charakter przede wszystkim literacki i historyczny, a w drugiej kolejności - społeczno-polityczny. „Wiadomości” były najważniejszym tygodnikiem tzw. Drugiej Wielkiej Emigracji, docierającym na wszystkie zamieszkałe przez człowieka kontynenty. Jan Kowalik nazwał czasopismo Grydzewskiego „warsztatem, szkołą i rozgłośnią radiową dla licznego zastępu poetów, pisarzy i publicystów, tworzących poza Krajem [...], katedrą historii kultury polskiej - nieistniejącą na żadnym $\mathrm{z}$ uniwersytetów krajowych - gdzie od lat, regularnie co tydzień odbywają

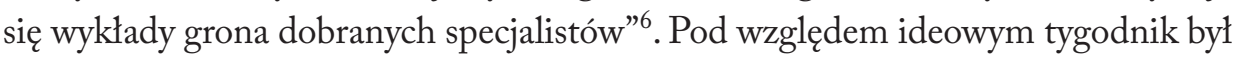
niepodległościowy i tradycjonalistyczny, a jednocześnie prezentował wyrażony eklektyzm poglądów.

Omawiana edycja jest kontynuacją ważnego w rozwoju edytorstwa naukowego zbioru listów Lechonia i Grydzewskiego przygotowanego io lat wcześniej przez Beatę Dorosz ${ }^{7}$. Natomiast na rok 2020 jest planowane wydanie korespondencji pomiędzy Wierzyńskim a Grydzewskim. W ten sposób zostanie sfinalizowany duży projekt edytorski, dzięki któremu historycy i miłośnicy literatury emigracyjnej zyskają cenną wiedzę z rozproszonych i trudno dostępnych listów znanych emigracyjnych autorów.

Tekstologiczno-edytorska praca wykonana przez Beatę Dorosz i Pawła Kądzielę (znanego wydawcę wielu nie tylko emigracyjnych źródeł) wymagała najpierw uporządkowania kolekcji listów, które były jedynie pozornie usystematyzowane i skompletowane. Kolejny zasadniczy etap stanowiło odczytanie korespondencji obu poetów (prawie w całości rękopiśmiennej), mimo istniejących odpisów części z nich na maszynie wykonanych lub zleconych przez Halinę Wierzyńską. Nie obyło się więc bez skonfrontowania maszynowych kopii z zachowanymi autografami, choć nie wiadomo, co się stało z niektórymi listami Wierzyńskiego. Tymczasem odczytanie odręcznego pisma, zwłaszcza Lechonia, było nie lada wyzwaniem. Wszak zdarzało

5 Por. R. Habielski, Nieztomni, nieprzejednani. Emigracyjne „Wiadomości” i ich krag 1940-1981, Warszawa 1991.

6 Zob. M. Lutomierski, Mickiewicz i okolice. Tematy romantyczne na tamach londyñskich „Wiadomości” z lat 40. i 50. XX wieku, Torun 2012, s. 16.

7 M. Grydzewski, J. Lechoń, Listy 1923-1956, oprac. B. Dorosz, t. 1-2, Warszawa 2006. 
się, że Wierzyński (a we wcześniejszej edycji również Grydzewski) sygnalizował niemożność „rozszyfrowania” rękopisu.

Niefunkcjonujące wcześniej w obiegu drukowanym listy poetów obrazują wieloletnią przyjaźń, którą Wierzyński określił jako podobną do związku rodzinnego. Niejako przy okazji poznajemy wojenne i powojenne tło życia Polaków na obczyźnie. W sposób szczególny widać w korespondencji zainteresowanie losami ludzi - zarówno bliskimi, jak i dalekimi znajomymi. Niektóre listy mają nawet charakter sprawozdań, w których „z obowiązku” trzeba wspomnieć o różnych osobach. Bez względu na ton tych wypowiedzi i stopień znajomości opisywanych lub wzmiankowanych postaci korespondencyjny dialog między poetami jest nasycony licznymi informacjami, anegdotami i plotkami, które z pewnością zainteresują biografów. Jednak trudno byłoby wyzyskać te źródła bez należytego opracowania, które w przypadku edycji Dorosz i Kądzieli stanowią starannie przygotowane komentarze w przypisach zamieszczonych po tekście każdego listu. Widać tu wnikliwość i rzetelność edytorów, którzy w odpowiednich proporcjach snują w pewnym sensie równoległą do treści listu opowieść, objaśniającą m.in. o kim (tu: najważniejsze fakty biograficzne lub odesłanie do właściwego tomu Wspótczesnych polskich pisarzy i badaczy literatury czy Polskiego stownika biograficznego) albo o czym (tu np.: publikacja z dokładnym adresem bibliograficznym; wydarzenia społeczno-kulturalne $z$ informacjami o dacie, miejscu, charakterze) mówi korespondencja poetów. Bardzo sporadycznie edytorzy przyznają, że nie udało im się ustalić, o kogo chodzi. Dodajmy jednak, że indeks nazwisk osób w różny sposób przywoływanych w listach obejmuje aż 26 stron, a objaśnienia dotyczyły ponadto również wielu innych zagadnień (np. politycznych czy społecznych). Dlatego wydawcy zamieścili następującą prośbę, która choć w pełni zrozumiała, to - niestety - nie jest często spotykana w edycjach naukowych. „Pomimo długotrwałych kwerend w archiwach i bibliotekach krajowych i zagranicznych niektórych spraw nie udało się objaśnić. Zwracamy się zatem do czytelników z prośbą o nadsyłanie na adres Wydawnictwa IBL ewentualnych uzupełnień lub sprostowań” (s. 26). Jak wiadomo, zainteresowanie Beaty Dorosz i Pawła Kądzieli edytorstwem listów emigracyjnych nie wygasło po wydaniu tego tomu.

Innym wyzwaniem, któremu znakomicie sprostali edytorzy, było ustalenie dokładnego datowania prawie połowy korpusu listów, ponieważ Lechoń i Wierzyński nie zostawili na ten temat precyzyjnych (a czasem wręcz żadnych) informacji. Ponadto edytorzy nadali listom numerację oraz umieścili informację o tym, kto jest nadawcą, a kto adresatem wypowiedzi. Po tekście korespondencji - ale jeszcze przed objaśnieniami, o których była już mowa - znajduje się metryczka listu z uwagami o technice zapisania tekstu, rodzaju papieru (łącznie z zaznaczeniem o nadruku), adresie, dacie powstania listu (jeśli nie jest znana) ustalonej przez edytorów (z za- 
znaczeniem na jakiej podstawie). Sądzę, że taki układ wydania źródła jest bardzo klarowny, uczciwy i funkcjonalny.

Podsumowując, chciałbym podkreślić, że niezwykle starannie opracowane wydanie listów Lechonia i Wierzyńskiego może być inspirującym przykładem dla edytorów XX-wiecznej korespondencji zarówno pod względem merytorycznym (praca tekstologiczna, biograficzna i historycznoliteracka), jak i formalnym (struktura i układ edycji). Mimo że jest to publikacja o charakterze specjalistycznym i jej głównymi adresatami są badacze literatury współczesnej, zwłaszcza emigracyjnej, ma ona również walor popularyzatorski. Wprowadza bowiem czytelnika nieprofesjonalnego w konteksty życia i twórczości poetów na obczyźnie, podając tekst źródłowy z opracowaniem niezbędnym do zrozumienia treści prezentowanej korespondencji. 